University of Nebraska - Lincoln

DigitalCommons@University of Nebraska - Lincoln

Faculty Publications from the Harold W. Manter Laboratory of Parasitology

6-1968

\title{
Three New Coccidia (Protozoa: Telosporea) from Kingsnakes, Lampropeltis spp., in Illinois, with a Redescription of Eimeria zamenis Phisalix, 1921
}

\author{
David R. Anderson \\ Colorado State University, anderson@cnr.colostate.edu \\ Donald W. Duszynski \\ University of New Mexico, eimeria@unm.edu \\ William C. Marquardt \\ Colorado State University
}

Follow this and additional works at: https://digitalcommons.unl.edu/parasitologyfacpubs

Part of the Parasitology Commons

Anderson, David R.; Duszynski, Donald W.; and Marquardt, William C., "Three New Coccidia (Protozoa: Telosporea) from Kingsnakes, Lampropeltis spp., in Illinois, with a Redescription of Eimeria zamenis Phisalix, 1921" (1968). Faculty Publications from the Harold W. Manter Laboratory of Parasitology. 114. https://digitalcommons.unl.edu/parasitologyfacpubs/114

This Article is brought to you for free and open access by the Parasitology, Harold W. Manter Laboratory of at DigitalCommons@University of Nebraska - Lincoln. It has been accepted for inclusion in Faculty Publications from the Harold W. Manter Laboratory of Parasitology by an authorized administrator of DigitalCommons@University of Nebraska - Lincoln. 


\title{
THREE NEW COCCIDIA (PROTOZOA: TELOSPOREA) FROM KINGSNAKES, LAMPROPELTIS SPP., IN ILLINOIS, WITH A REDESCRIPTION OF EIMERIA ZAMENIS PHISALIX, 1921
}

\author{
David R. Anderson, * Donald W. Duszynski, and William C. Marquardt \\ Department of Zoology, Colorado State University, Ft. Collins, Colorado 80521
}

\begin{abstract}
Eimeria lampropeltis sp. n., Caryospora lampropeltis sp. $\mathrm{n}$. , and Cryptosporidium lampropeltis sp. n. are described from the host Lampropeltis c. calligaster, and Eimeria zamenis is redescribed from this host and from L. getulus holbrooki. Oocysts of E. lampropeltis are ellipsoidal with a smooth outer wall measuring 29 to 38 by 14 to $20 \mu$, mean 30.4 by 16.3 . E. zamenis oocysts are ellipsoidal with a smooth outer wall measuring 28 to 33 by 14 to $19 \mu$, mean 30.2 by 16.2 . Oocysts of Caryospora lampropeltis are round with a finely pitted outer wall measuring 20 to $25 \mu$ in diameter, mean 23.3. Each oocyst contains one thick-walled sporocyst with a prominent Stieda body and eight bananashaped sporozoites. Cryptosporidium lampropeltis oocysts are ovoid with a thin, smooth outer wall measuring 10 to 12 by 8 to $9 \mu$, mean 10.9 by 8.1 . Each oocyst contains four sporozoites which measure 6 to 8 by 1 to $2 \mu$, mean 7.0 by 1.9 .
\end{abstract}

Two kingsnakes, Lampropeltis c. calligaster, the prairie kingsnake, and L. getulus holbrooki, the speckled kingsnake, were captured in Jackson County, Illinois, in April 1965, and September 1966, respectively. Shortly after capture, they were transported to Fort Collins, Colorado, and kept in cages. Fecal examinations made in 1966 and 1967 showed the presence of oocysts of four species of coccidia. One of these, Eimeria zamenis, has not been adequately described (Phisalix, 1921; Roudabush, 1937), and the other three appear to be new species.

\section{MATERIALS AND METHODS}

The snakes were caged together except for short periods when they were separated in order to collect fecal samples. They were fed various species of mice at irregular intervals.

The presence of coccidia was determined by concentrating the oocysts using cover slip flotation with Sheather's sugar solution. Oocysts were allowed to sporulate by diluting the fecal material with $2.5 \%$ aqueous potassium dichromate and placing it in an incubator at $20 \mathrm{C}$ for 5 days. The oocysts were then stored in a refrigerator at $5 \mathrm{C}$.

Sporulated oocysts were examined using a compound microscope equipped with a $100 \times$ achromatic oil immersion objective. Further examinations and photomicrographs were made using microscopes equipped with fluorite and apochro-

Received for publication 26 January 1968.

* Present address: The Pennsylvania State University, Fayette Campus, Uniontown, Pennsylvania 15401 .

Supported, in part, by a Training Grant, No. 5TI AI 94-08 from the NIAID, NIH, U. S. Public Health Service. matic oil immersion objectives. By sliding the cover slip back and forth over the oocysts, friction caused the layers of the walls, if more than one, to separate, enabling us to determine the number of oocyst walls in every case. Oocysts were measured using an ocular micrometer and drawings were made as composites from measurements and photomicrographs. Statistical data for each species are based on measurements of 50 oocysts. All measurements are in microns, with means given in parentheses following the range.

\section{RESULTS AND DISCUSSION}

\section{Eimeria zamenis Phisalix, 1921}

(Figs. 1, 6, 7)

Morphology: Sporulated oocysts ellipsoidal or slightly ovoid with bright yellow, smooth outer wall of uniform thickness. Micropyle absent. Oocyst usually wider slightly below the middle. Wall thickness about 1; composed of single layer. Fifty sporulated oocysts measured 28 to 33 by 14 to 19 ( 30.2 by 16.2$)$. Shape index 1.53 to 2.23 (1.87). Oocyst residuum and polar body absent. Sporocysts round to slightly ellipsoidal measuring 8 to 11 by 7 to 10 ( 9.4 by 7.8 ). Shape index 1.00 to 1.50 (1.21). Stieda body lacking. Sporozoites elongate-ellipsoidal, approximately 2 wide and lying side by side, usually extending the full length of the sporocyst. Irregular sporocyst residuum present in addition to one to three clear, homogeneous globules per sporocyst.

Sporulation time: Unknown. However, it appears that this species sporulates upon leaving the tissues as no unsporulated oocysts were observed in numerous fecal examinations. This is, in part, supported by Roudabush (1937) who found both sporulated and unsporulated oocysts in the gallbladder and many empty oocysts in the bile. The latter indicates in vivo excystation and autoinfection.

Hosts: Coluber (= Zamenis) sp., C. constrictor, 

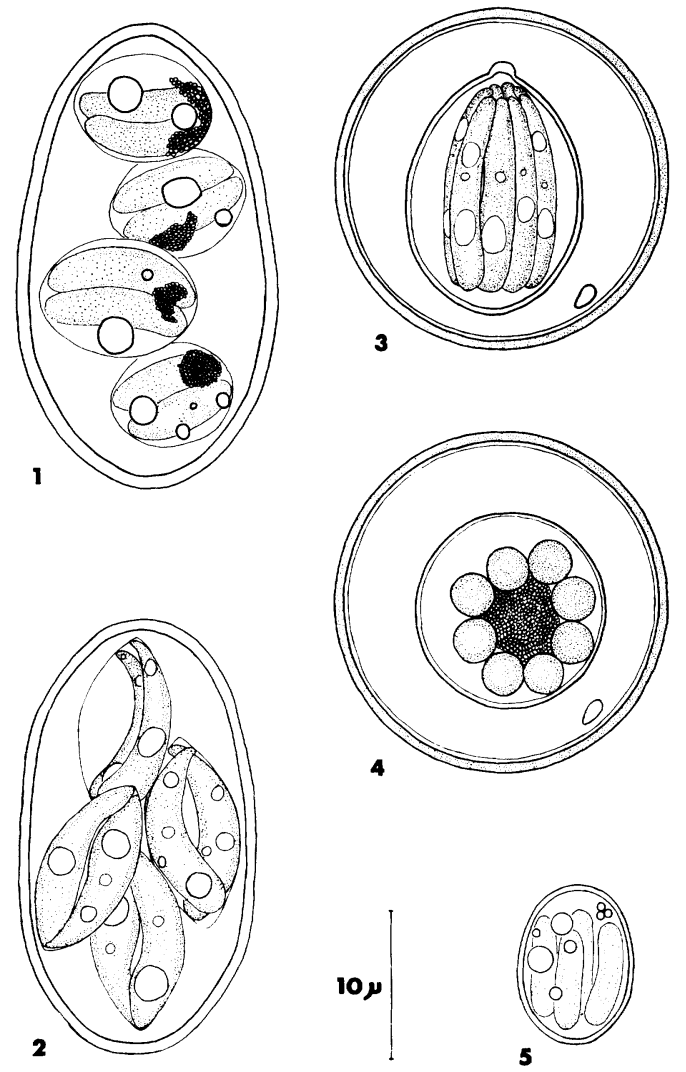

Figures 1-5. Coccidia from the kingsnake in Illinois. 1. Eimeria zamenis Phisalix, 1921, from Lampropeltis c. calligaster and L. getulus holbrooki. 2. Eimeria lampropeltis sp. n. from L. $c$. calligaster. 3. Caryospora lampropeltis $\mathrm{sp}$. n. from L. c. calligaster. 4. C. lampropeltis, showing end view of sporocyst. 5. Cryptosporidium lampropeltis sp. n. from L. c. calligaster.

C. c. flaviventris, Masticophis f. flagellum, Lampropeltis c. calligaster, and L. getulus holbrooki.

Location in host: Gallbladder.

Locality: Brazil (?), Iowa (?), and Illinois.

\section{Eimeria lampropeltis sp. $\mathbf{n}$.}

(Figs. 2, 8, 9)

Morphology: Sporulated oocysts ellipsoidal with bright yellow, smooth outer wall of uniform thickness. Micropyle absent. Wall thickness about 1; composed of single layer. Fifty sporulated oocysts measured 29 to 38 by 14 to 20 ( 30.4 by 16.3 ). Shape index 1.69 to 2.08 (1.85). Oocyst residuum and polar body absent. Thin-walled, elliptical sporocysts pointed at both ends, measure 12 to 15 by 4 to 9 ( 13.9 by 7.3 ). Shape index 1.62 to 3.53 (1.98). Stieda body lacking. Sporozoites bananashaped, rounded at one end and tapering to a point at the other. Sporozoites arranged both side by side and "head to tail" in sporocysts in the same oocyst, the latter arrangement most common, in both instances, extending to ends of sporocyst. Sporocyst residuum absent. Sporozoites contain varying numbers of refractile globules.

Sporulation time: Unknown, but only sporulated oocysts were observed in fresh fecal examinations.

Host: Lampropeltis c. calligaster.

Location in host: Unknown; oocysts found in feces.

Locality: Jackson County, Illinois.

\section{Remarks}

Eimeria zamenis was found in both the prairie and speckled kingsnakes. Our observations compared to the two previous reports of this parasite indicated clearly that we were dealing with E. zamenis (Table I). Phisalix's original description (1921) had no accompanying drawings or photographs and she neglected to mention, as did Roudabush (1937), the number of oocysts measured in making her somewhat sketchy description. Also, the locality and host species were left as uncertainties. Evidently, she had described this species from a snake, Zamenis sp. (?) which had died in 1920, in a zoological garden (ménagerie des reptiles du Muséum) somewhere in France. She stated that the snake probably originated in Brazil, but that she had not made a positive identification of it at that time. Roudabush (1937) presented a somewhat more complete description of the parasite, including information on its location in the host. He described the parasite from three species of racers but neglected to state definitely the locality where the hosts had been obtained. He pointed out, however, in reference to Phisalix (1921), that the genus Zamenis had been shown to be the same as the genus Coluber supporting his decision that the coccidium found in the racers he examined was, in fact, E. zamenis.

Under low magnification, E. zamenis and

Figures 6-13. Coccidia from kingsnake, cont'd. 6, 7. Eimeria zamenis Phisalix, 1921, from Lampropeltis c. calligaster and L. getulus holbrooki. 8, 9. Eimeria lampropeltis sp. n. from L. c. calligaster. 10, 11. Caryospora lampropeltis sp. n. from L. c. calligaster. 12. Cryptosporidium lampropeltis sp. $\mathrm{n}$. from L. c. calligaster. 13. Caryospora lampropeltis showing end view of sporocyst. 


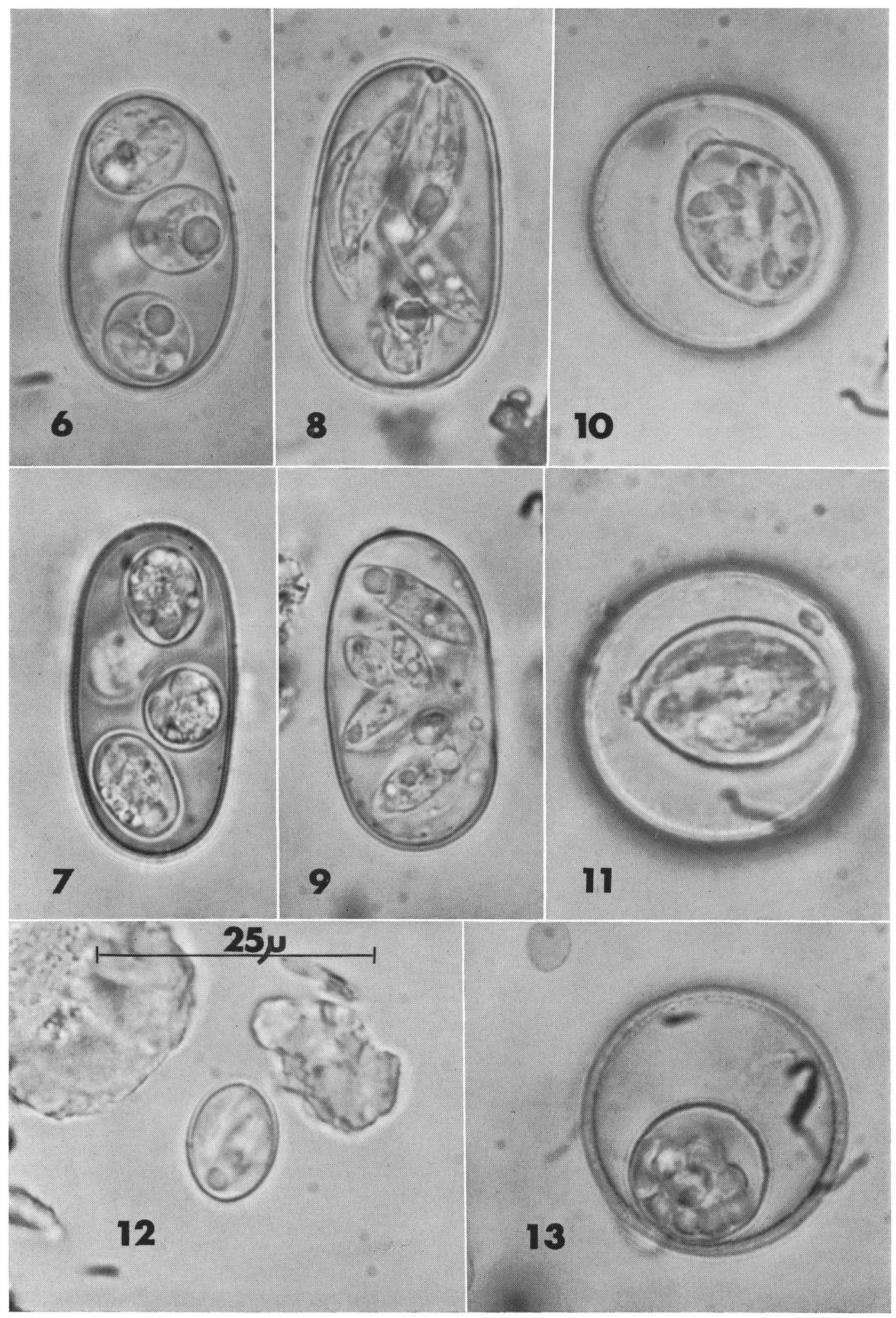


TABLE I. Comparison of Eimeria zamenis of snakes from various sources.

\begin{tabular}{|c|c|c|c|}
\hline & Phisalix (1921) & Roudabush (1937) & Present study \\
\hline $\begin{array}{l}\text { Oocyst } \\
\quad \text { shape } \\
\text { size in } \mu \\
\text { residuum } \\
\text { color }\end{array}$ & $\begin{array}{l}\text { elliptical } \\
28-30 \times 15-18 \\
? \\
?\end{array}$ & $\begin{array}{l}\text { elliptical } \\
31-35 \times 17-20(32.7 \times 17.8) \\
0 \\
?\end{array}$ & $\begin{array}{l}\text { elliptical } \\
28-33 \times 14-19(30.2 \times 16.2) \\
\quad 0 \\
\text { yellow }\end{array}$ \\
\hline $\begin{array}{l}\text { Sporocyst } \\
\text { shape } \\
\text { size in } \mu \\
\text { residuum }\end{array}$ & $\begin{array}{c}\text { round } \\
10 \\
+\end{array}$ & $\begin{array}{l}\text { round to ovate } \\
8-11 \times 7-10(9.8 \times 8.8) \\
\quad+\end{array}$ & $\begin{array}{l}\text { round to ovate } \\
8-11 \times 7-10(9.4 \times 7.8) \\
\quad+\end{array}$ \\
\hline Locality & Brazil (?) & Iowa (?) & Illinois \\
\hline Hosts & Coluber (= Zamenis) sp. & $\begin{array}{l}\text { C. constrictor } \\
\text { C. } \text { c. flaviventris } \\
\text { Masticophis f. flagellum }\end{array}$ & $\begin{array}{l}\text { Lampropeltis c. calligaster } \\
\text { L. getulus holbrooki }\end{array}$ \\
\hline Location in host & gallbladder & gallbladder & ? \\
\hline
\end{tabular}

E. lampropeltis appear to be similar since their size, shape, and color are much the same. Under higher magnification, however, certain differences are evident. E. zamenis tapers toward one end, whereas E. lampropeltis is more nearly ellipsoidal. The sporocysts in $E$. zamenis are smaller and have a definite rounded shape whereas those of $E$. lampropeltis have walls so thin that they sometimes cannot be seen. When visible, their shape is regular with the ends being bluntly pointed. The sporozoites in E. zamenis lie next to each other only partially filling the sporocyst. In E. lampropeltis, however, the sporozoites usually fill the sporocyst but sometimes lie side by side in such a way that a large vacant space remains on one side of the sporocyst (Fig. 2).

Phisalix (1921) and Roudabush (1937) had found sporulated oocysts of E. zamenis in the gallbladder and the latter reported empty oocysts in the bile and speculated that the sporozoites excyst in the bile and reinfect the same host. This study offers some support to that statement since the hosts had continually passed oocysts in their feces for over 12 months. Oocysts of E. lampropeltis were also observed in the feces over this same period.

E. lampropeltis does not resemble any of the ophidian Eimeriidae reported by Pellérdy (1965) nor does it resemble the only report since that publication of a snake coccidium by Van Peenen et al. (1967).

\section{Caryospora lampropeltis sp. $\mathbf{n}$.}

(Figs. 3, 4, 10,11, 13)

Morphology: Sporulated oocysts round with finely pitted outer wall of uniform thickness, yellow to light green in color. Inner wall transparent, of uniform thickness. Total thickness of walls about 1. Fifty sporulated oocysts measured 20 to 25 (23.3) in diameter. Shape index 1. Micropyle lacking. Polar body present. Oocysts with one thick-walled ovoid sporocyst measuring 15 to 19 by 11 to 13 ( 17.1 by 12.3). Shape index 1.25 to 1.60 (1.39). Prominent Stieda body present. Substiedal body present but usually obscured by sporozoites (Figs. 3, 10, 11). Sporozoites bananashaped, about 13 long, 3 wide at thicker end. In optical section eight sporozoites arranged side by side in circle enclosing central residual body, usually lying to one side of the sporocyst (Figs. $4,13)$. Sporozoites contain varying numbers of refractile globules.

Sporulation time: Most oocysts were sporulated after 5 days at $20 \mathrm{C}$.

Host: Lampropeltis c. calligaster.

Location in host: Unknown; oocysts found in feces.

Locality: Jackson County, Illinois.

\section{Remarks}

Nine species of Caryospora, none in North or Central America, have been reported, to date, from ophidian hosts and all are listed in Pellérdy (1965). Caryospora brasiliensis, described by Carini, 1932, from Chlorosoma aestivum, the green cobra, in Brazil, is the only one of the nine that resembles the species with which we are dealing. The oocyst of C. brasiliensis measured 20 to 22 in diameter and the single sporocyst is reported to average 17 by 13 . These measurements fall into the range of C. lampropeltis; however, the sporozoites of $C$. brasiliensis are stout, blunt at both ends and randomly arranged, and the sporocyst residuum consists of small scattered granules. In addition, the differences in hosts and geographical location lead us to believe the organism we have described is a new species. 


\section{Cryptosporidium lampropeltis sp. $\mathbf{n}$.}

(Figs. 5, 12)

Morphology: Sporulated oocysts ovoid with light yellow to almost colorless, smooth outer wall of uniform thickness. Wall thickness less than 1 ; composed of single layer. Fifty sporulated oocysts measured 10 to 12 by 8 to 9 ( 10.9 by 8.1 ). Shape index 1.25 to 1.42 ( 1.34 ). Oocyst residuum present consisting of two to many clear globules of varying sizes. Polar body and micropyle absent. Oocysts with four thin-walled elongate-ellipsoidal sporozoites measuring 6 to 8 by 1 to $2(7.0$ by 1.9). Shape index 3.00 to 7.00 (3.69). Sporozoites contain one, terminal refractile globule.

Sporulation time: All oocysts observed were sporulated after 5 days at $20 \mathrm{C}$ but it is not known whether sporulated oocysts are shed in the feces since this species was not observed in examining fecal samples prior to incubation.

Host: Lampropeltis c. calligaster. feces.

Location in host: Unknown; oocysts found in

Locality: Jackson County, Illinois.

\section{Remarks}

In the description of Isospora dirumpens americana var. n., Roudabush (1937) related his initial encounter with that parasite as cysts containing four sporozoites and a residual body and mentioned that he had first thought they were Cryptosporidium oocysts. Further study revealed the presence of two of the cysts enclosed in a thin outer membrane, thus showing that the cysts were really sporocysts of Isospora. Aware of this possibility, we even- tually expected to encounter similar results after first observing the cyst described above. However, in at least 10 detailed fecal observations, no two cysts were ever observed together nor was any structure resembling the remnants of an oocyst membrane ever seen. The invariable presence of four sporozoites within the cyst precludes it from being a free sporocyst of $E$. zamenis. To our knowledge no species of Cryptosporidium has been reported from ophidians.

\section{ACKNOWLEDGMENTS}

Appreciation is expressed to Mr. John Hess, Department of Zoology, Colorado State University, who collected the snakes and whose cooperation made this study possible.

\section{LITERATURE CITED}

CARINI, A. 1932. Caryospora brasiliensis n. sp., parasita do intestine da cobra verde, Chlorosoma aestivum. Rev. Biol. Hyg. (S. Paulo) 3: $85-87$.

Pellérdy, L. P. 1965. Coccidia and Coccidiosis. Hungarian Acad. Sci., Budapest, p. 112-128.

Phisalix, M. 1921. Coccidiose des serpents. Bull. Soc. Path. Exot. 14: 82-84.

Roudabush, R. L. 1937. Some coccidia of reptiles found in North America. J. Parasit. 23 : 354-359.

Van Peenen, P. F. D., P. F. Ryan, and T. J. MCINTyre. 1967. Eimeria korros and E. modesta spp. n. (Protozoa: Eimeriidae) from a snake and a tree shrew in South Vietnam. J. Parasit. 53 : 1148-1150. 